\title{
EFFECTS OF MINERAL ADMIXTURE ON THE CARBONIC ACID LEACHING RESISTANCE OF CEMENT-BASED MATERIALS
}

\author{
YUN DONG*, LEI WANG*, HUAQUANYANG*, ${ }^{*}$ MEIJUAN RAO** \\ *ChangjiangRiver Scientific Research Institute, \\ No. 23 Huangpu Street, Wuhan, 430010, China \\ **State Key Laboratory of Silicate Materials for Architectures, Wuhan University of Technology, \\ No. 122 Luoshi Street, Wuhan, 430070, China \\ \#E-mail: raomeijuanding@163.com
}

Submitted September 9, 2016; accepted April 26, 2017

\begin{abstract}
Keywords: Cement-based materials, Carbonic acid leaching, Mass loss, Leaching resistance factor
In order to reveal the degradation process and deterioration mechanism of cement-based materials, this paper analyzes the effects of carbonic acid leaching on the mechanical strength of mortars, as well as relative mass loss, microstructure, and composition of various cement pastes. The results indicate that cement pastes containing less than $20 \%$ fly ash have higher carbonic acid leaching resistance than cement pastes without fly ash. However, after carbonic acid leaching, the compressive strength of the samples with fly ash is lower than that of the cement pastes without fly ash. The leaching resistance is good for samples cured at an early age before leaching. Carbonic acid leaching proceeds from the paste surface to the interior. The incorporation of an appropriate amount of slag powder helps to increase the density of the paste. Due to the pozzolanic activity of fly ash at late-stage leaching, a mixture of fly ash ( $\leq 20 \%)$ and slag powder ( $\leq 20 \%)$ effectively improves carbonic acid leaching resistance. The products of early-stage leaching were mainly $\mathrm{CaCO}_{3}$ and small amounts of $\mathrm{SiO}_{2}$ and $\mathrm{Fe}_{2} \mathrm{O}_{3}$. The $C-S-H$ phase at the paste surface suffered serious damage after long periods of leaching, and the main products of leaching were $\mathrm{SiO}_{2}$ and $\mathrm{Fe}_{2} \mathrm{O}_{3}$.
\end{abstract}

\section{INTRODUCTION}

Water with high contents of carbonic acid is commonly found on the sites of hydroelectric projects [1]. Most of these projects are situated in wet, hot and rainy environments [2]. There is usually luxuriant vegetation along the riverbank, with large amounts of humus accumulated both along the bank and at the bottom of the river [3]. When the permeability of the soil layer is bad anaerobic bacteria are present, and organic fertilizers in the soil will be resolved and produce abundant amounts of $\mathrm{CO}_{2}$ under the actions of these bacteria. According to the equilibrium concentrations of calcium hydroxide (the limit concentration of lime), hydration products will gradually dissolve or decompose when the concrete cement is in long-term contact with "soft" water (i.e. water containing less or no soluble calcium and magnesium compounds) [4-7]. This is the dissolution part of leaching. Portland cement hydration products are alkaline substances, which are soluble in water to some extent. They do not dissolve in water and are stable only if the lime content in the liquid phase is above the respective limit concentration of the hydration products. On the contrary, when the lime content in the liquid phase is below the limit concentration of hydration products, the hydration products will decompose and release lime, resulting in a change of high-calcium hydration products into low-calcium hydration products [8]. Calcium hydroxide, which has the largest limit concentration of lime in hydration products, will be the first to dissolve out when the cement comes into contact with "soft" water. The water around the cement is easily saturated by the calcium hydroxide, which in the case of non-pressurized static water will discontinue dissolution. In this case, the dissolution is limited to the surface layer, which has little effect on the concrete [9-10]. From the aforesaid it is clear that the degree of dissolution leaching is related to the "hardness" of the water, the density of the concrete, and the environmental conditions.

Researchers have attached great importance to the study of concrete durability in recent years, and a large number of systematic tests have been conducted in the study of single-factor damage on concrete. Environmental factors, climatic conditions, and loads can affect the performance of engineering concrete, whereas the interactions of these may further influence the durability of the concrete. When the content of carbon dioxide $\left(\mathrm{CO}_{2}\right)$ is too high in the water, the concrete will begin to corrode. It has been established in "The geographic survey code of hydroelectric project"(GB 50287-2006) [11] that water with free $\mathrm{CO}_{2}$ concentrations higher than $15 \mathrm{mg} \cdot \mathrm{l}^{-1}$ is carbonic acid leaching type water. The free 
$\mathrm{CO}_{2}$ does not act as a corrosion agent, when it is just dissolved in the water as a gas molecule, but in the ionic state $\left(\mathrm{CO}_{3}{ }^{2-}\right)$ in water it becomes carbonic acid, which is a corrosion agent [12]. The $\mathrm{CO}_{2}$ balanced in water by calcium cations forming calcium bicarbonate (so-called "balance $\mathrm{CO}_{2}$ ") has no corrodibility, whereas the remaining $\mathrm{CO}_{2}$ is corrosive [13]. The carbonic acid (i.e. the corrosive carbon dioxide) will participate in chemical reactions with the alkaline cement pastes in the concrete and produce carbonates, which can be easily dissolved in water, damaging the cement-based materials [14].

Currently, there are but a few studies on the carbonic acid corrosion of concrete used for dam construction [15]. This work simulates carbonic acid type water and, for the first time, studies the effects of carbonic acid leaching on the mechanical strength of mortars, as well as the relative mass loss, microstructure, and composition of various cement pastes.

\section{EXPERIMENTAL}

\section{Materials}

For the experiments in this work P·MH 42.5 Portland cement, Grade I fly ash and slag powder were used. For the mortar test the standard sand required by "The standard sand applied for the cement strength test" (GB 178-1997) [16] and highly pure (HP) canned carbon dioxide gas for industrial production were used.

\section{Preparation and test method}

The water-cement ratio (W/C)used for preparing the cement paste and mortar is 0.5 , the ratio of cement and sand for preparing the mortar is $1: 3$. The dimensions of the paste test specimens are $2 \mathrm{~cm} \times 2 \mathrm{~cm} \times 2 \mathrm{~cm}$, which is adapted to the water consumption of the cement standard. The amount of replacement in the paste and mortar used in the test is $0 \%, 20 \%$ and $40 \%$ of fly ash or slag powder, respectively. The paste specimen is weighed, and the compressive strength of the mortar piece is tested (using a WYA-2000 Electro hydraulic pressure testing machine) at the observation age and compared with the specimen kept under standard curing conditions. After stopping the hydration of the paste specimen with anhydrous ethanol the samples are characterized via X-ray diffraction (XRD, Bruker Advance D8, scan interval 5-60 2 $\theta$ ) and Fourier transform infrared spectroscopy (FTIR, Thermo Nicolet Nexus 470).

The highly pure carbon dioxide is dissolved in water in order to prepare the water with corrosive carbon dioxide for the tests. The paste and mortar specimens, which have different mix proportions, are immersed into the test piece drum, 21 of pure water are added, the drum is covered and carbon dioxide is introduced. The carbon dioxide flow is regulated to make the flow of the carbon dioxide similar in all cases. Carbon dioxide is introduced for one hour each time in intervals of 6 hours, the concentration of the carbon dioxide in water is kept at an average of $80 \mathrm{mg} \cdot \mathrm{l}^{-1}$ and the water temperature is kept at approximately $20^{\circ} \mathrm{C}$. The water is changed every day for a period of 7 days. After that period, the water is changed each week until the end of the test.

\section{RESULTS AND DISCUSSION}

\section{Cement paste mass loss and calcium leaching}

Figure 1 shows that the relative mass loss of cement pastes, whether pure or mixed with fly ash and/or slag,

Table 1. Physical and mechanical properties of the cement used.

\begin{tabular}{|c|c|c|c|c|c|c|c|c|c|c|c|}
\hline \multirow{2}{*}{$\begin{array}{c}\text { Specific } \\
\text { surface area } \\
\left(\mathrm{m}^{2} \cdot \mathrm{kg}^{-1}\right)\end{array}$} & \multirow[t]{2}{*}{$\begin{array}{l}\text { Density } \\
\left(\mathrm{g} \cdot \mathrm{cm}^{-3}\right)\end{array}$} & \multirow[t]{2}{*}{ Stability } & \multirow{2}{*}{$\begin{array}{c}\text { Standard } \\
\text { consistency } \\
(\%)\end{array}$} & \multicolumn{2}{|c|}{$\begin{array}{c}\text { Setting } \\
\text { time (min) }\end{array}$} & \multicolumn{3}{|c|}{$\begin{array}{l}\text { Compressive } \\
\text { strength (MPa) }\end{array}$} & \multicolumn{3}{|c|}{$\begin{array}{c}\text { Flexural } \\
\text { strength }(\mathrm{MPa})\end{array}$} \\
\hline & & & & Initial & Final & $3 \mathrm{~d}$ & $7 d$ & $28 \mathrm{~d}$ & $3 \mathrm{~d}$ & $7 d$ & $28 \mathrm{~d}$ \\
\hline 301 & 3.15 & qualified & 24.6 & 187 & 283 & 22.3 & 29.0 & 43.0 & 6.16 & 7.21 & 9.55 \\
\hline
\end{tabular}

Table 2. Chemical composition of the cement (\%).

\begin{tabular}{ccccccccc}
\hline $\mathrm{CaO}$ & $\mathrm{SiO}_{2}$ & $\mathrm{Al}_{2} \mathrm{O}_{3}$ & $\mathrm{Fe}_{2} \mathrm{O}_{3}$ & $\mathrm{MgO}$ & $\mathrm{SO}_{3}$ & $\mathrm{~K}_{2} \mathrm{O}$ & $\mathrm{Na}_{2} \mathrm{O}$ & Loss of ignition \\
\hline 61.21 & 21.36 & 3.57 & 4.67 & 5.25 & 2.15 & 0.31 & 0.09 & 1.26 \\
\hline
\end{tabular}

Table 3. Main technological parameters of fly ash and slag powder.

\begin{tabular}{lccccccc}
\hline & $\begin{array}{c}\text { Density } \\
\left(\mathrm{g} \cdot \mathrm{cm}^{-3}\right)\end{array}$ & $\begin{array}{c}\text { Fineness } \\
(\%)\end{array}$ & $\begin{array}{c}\text { Water demand ratio } \\
(\%)\end{array}$ & $\begin{array}{c}\text { Loss of ignition } \\
(\%)\end{array}$ & $\begin{array}{c}\text { Water content } \\
(\%)\end{array}$ & $\begin{array}{c}\mathrm{SO}_{3} \\
(\%)\end{array}$ & $\begin{array}{c}\text { 28d activity index } \\
(\%)\end{array}$ \\
\hline Fly ash & 2.32 & 7.7 & 94.0 & 1.74 & 0.13 & 1.41 & 86 \\
Slag powder & 3.0 & - & - & 1.28 & 0.23 & 0.83 & 101 \\
\hline
\end{tabular}


increases with leaching time in an approximately linear fashion. Already after a few days of leaching, the relative mass loss of the pure cement paste is higher than that of cement pastes with fly ash and/or slag powder.

When mixed with $20 \%$ of fly ash, the relative mass loss is lower than that of pure cement paste (for each period of leaching). The latter can be associated with the high content of $\mathrm{Ca}(\mathrm{OH})_{2}$ (denoted shortly $\mathrm{CH}$ in the sequel) in the cement paste. It is also evident that the relative mass loss of the cement paste with $20 \%$ fly ash tends to be slightly lower than that of a paste with $20 \%$ slag powder. In particular, composite cement pastes doped with both fly ash and slag powder exhibit the minimum mass loss. This demonstrates that cementbased materials with a small and highly specific amount of fly ash and slag powder can be relatively resistant against carbonic acid leaching. The hydration product structure on the cement surface is destroyed and calcium is leached out during carbonic acid leaching. Figure 2 presents the relationship between leaching time and $\mathrm{Ca}^{2+}$ content in the leaching solution, where the quality of the specimens deteriorated and the porosity increased due to leaching. In addition, carbonic acid further reacted with the inner layer of hydration products, thus accelerating the leaching.

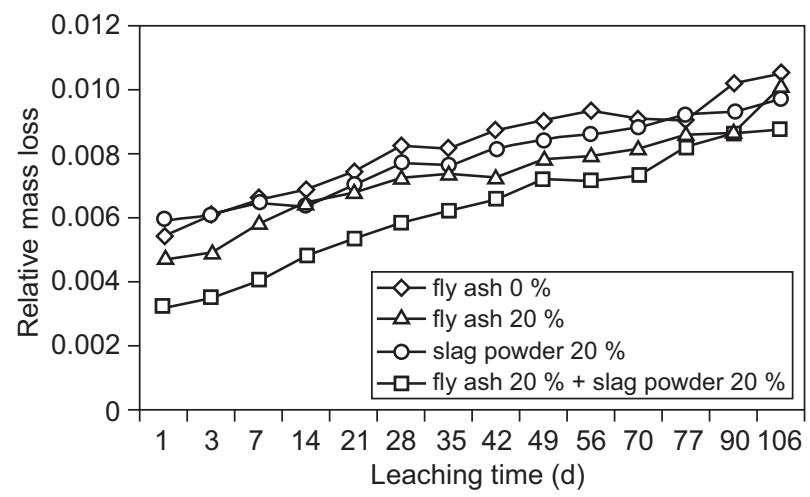

Figure 1. Relationship between the leaching time and relative mass loss of the cement paste.

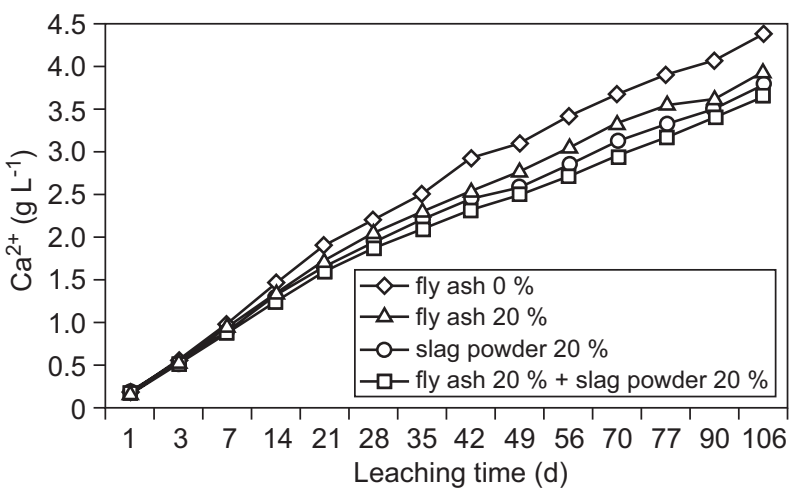

Figure 2. Relationship between the leaching time and $\mathrm{Ca}^{2+}$ content of the leaching solution.

\section{Compressive strength tests}

\section{Leaching of uncured samples}

Figure 3 shows the compressive strength of the uncured mortar in dependence of the leaching time. After leaching for more than $28 \mathrm{~d}$ the compressive strength of cement mortar mixed with $20 \%$ fly ash or slag powder or both is higher than that of the pure cement mortar. When the content of fly ash or slag powder is below $20 \%$, the compressive strength is relatively close to that of cement paste without replacements. The compressive strength of mortar mixed with $40 \%$ fly ash or slag powder is significantly lower than that of the cement mortar without replacements (for arbitrary leaching times).

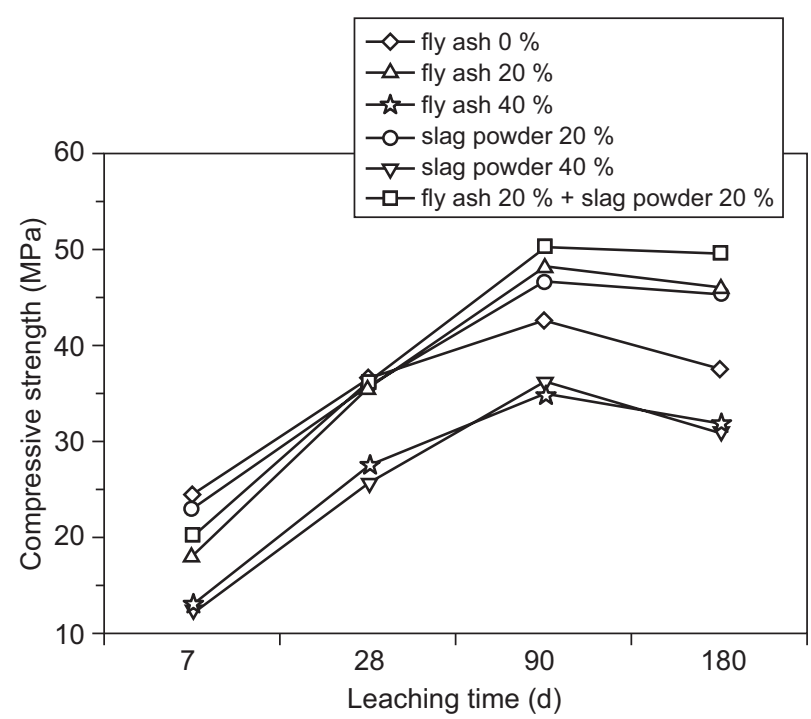

Figure 3. Relationship of leaching time and the compressive strength of cement mortar.

\section{Samples cured in water for 7 days at $20^{\circ} \mathrm{C}$ before leaching}

As can be seen in Figure 4, within 28 days the mortar compressive strength gradually increased despite the leaching, and began to decrease only after leaching for more than 28 days and only in the case of cement mortar without fly ash. When mixed with slag powder, the mortar compressive strength increased slightly after leaching for more than 90 days. It has to be noted that even after leaching for only seven days, the compressive strength of post-leaching specimens was higher than the strength of specimens cured under standard conditions. This may be linked to the effects of the calcium carbonate generated by carbonate ions and calcium hydroxide, which may have blocked the surface pores, making the samples denser. With a slag powder content of $20 \%$, the compressive strength of mortar specimens mixed with slag powder was significantly lower than that of those without slag powder. This trend was especially 
pronounced in the early stages of leaching. The leaching resistance of the mortar specimens was poor when the slag powder content reached $40 \%$.

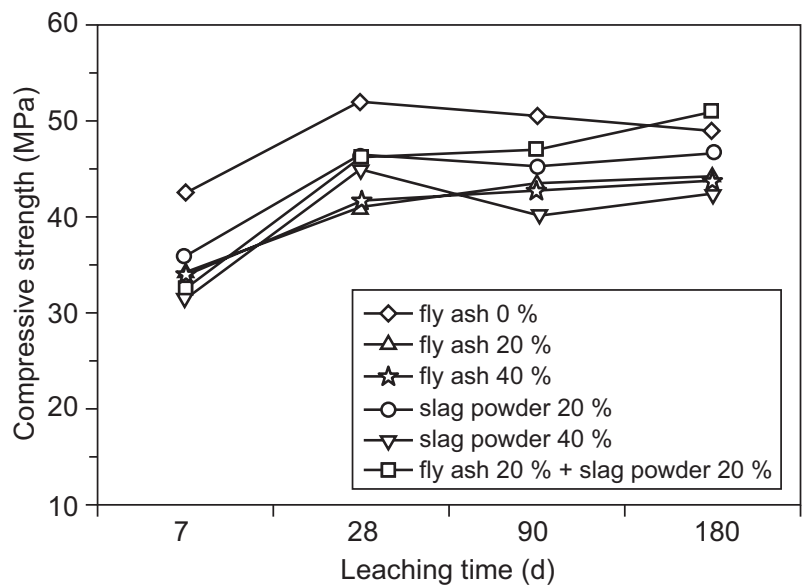

Figure 4. Relationship of the leaching time and the compressive strength of specimens (cured in water for 7 days).

\section{Samples cured in water for 28 days at $20^{\circ} \mathrm{C}$ before leaching}

Similarly to the specimens cured in water for seven days at $20^{\circ} \mathrm{C}$ prior to leaching, the test results (Figure 5) showed that mortar compressive strength gradually increased as the leaching age increased within 90 days.

With $20 \%$ slag powder content, the mortar specimens mixed with slag powder exhibited leaching resistance superior to the specimens without slag powder. However, resistance was poor for specimens with $40 \%$ slag powder content and the mortar strength of some of the specimens with $20 \%$ slag powder significantly decreased for a leaching time of 180 days. The performance was relatively good for the specimens mixed with both slag powder $(20 \%)$ and fly ash $(20 \%)$, and comparable to that of the specimens cured in water for seven days at $20^{\circ} \mathrm{C}$.

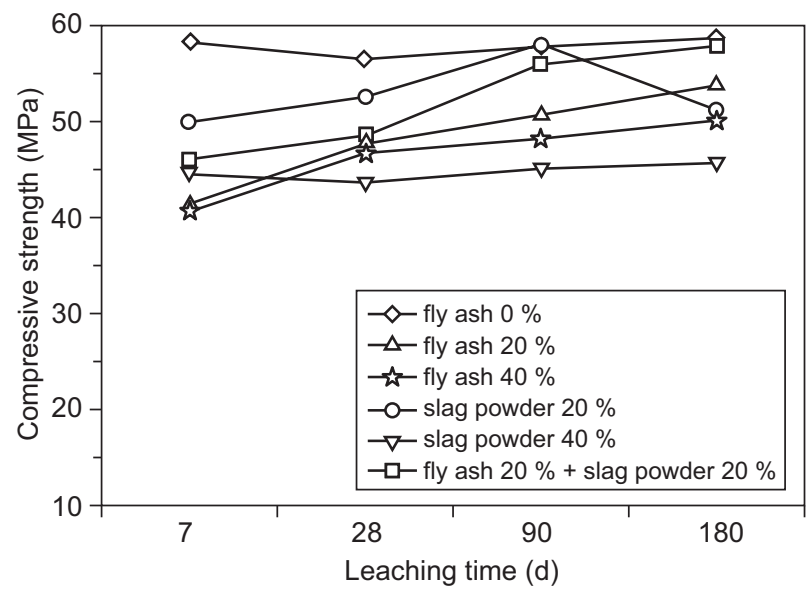

Figure 5. Relationship of the leaching time and the compressive strength of specimens (cured in water for 28days).
Phase analysis

$X$-ray diffraction

\section{1) Uncured samples}

Figure 6 shows the XRD patterns of samples taken from the surface and the interior of cement paste bodies after carbonic acid leaching at varying ages(out-surface; in-interior). At a hydration time of seven days, the cement paste's $\mathrm{CH}$ content was significantly reduced after leaching. The diffraction peaks of $\mathrm{CaCO}_{3}$ in the pure cement paste (without fly ash or slag powder) hydrated for 90 days disappeared.

At the sample surface the peaks corresponding to calcium carbonate increased significantly at a hydration time of seven days, but disappeared after 90 days. In addition, we found that the surface samples also showed peaks ascribed to $\mathrm{SiO}_{2}$, while the samples from the interior did not. This indicates that the $\mathrm{SiO}_{2}$ phase was a product of carbonic acid leaching. At a hydration time of 90 days, the $\mathrm{SiO}_{2}$ diffraction peaks were enhanced and we also found diffraction peaks of ferrite phases.

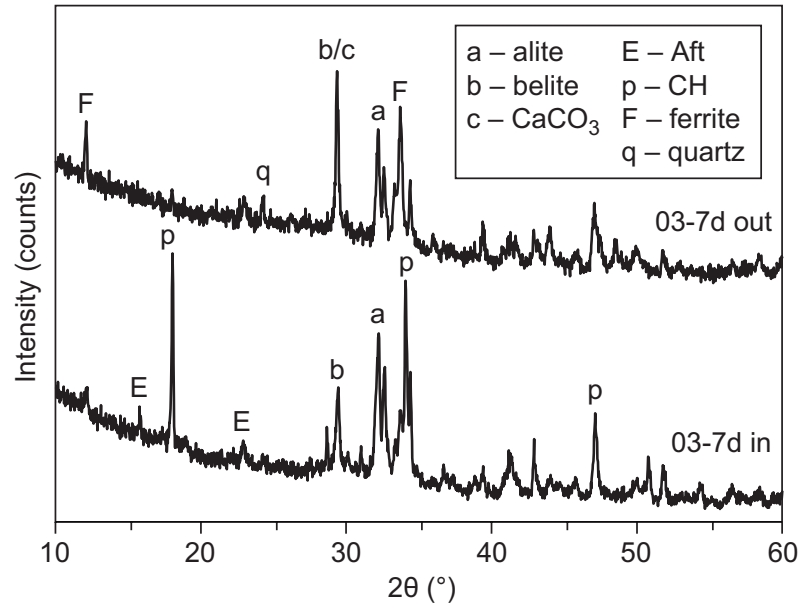

a) Hydrated cement paste after 7 days leaching

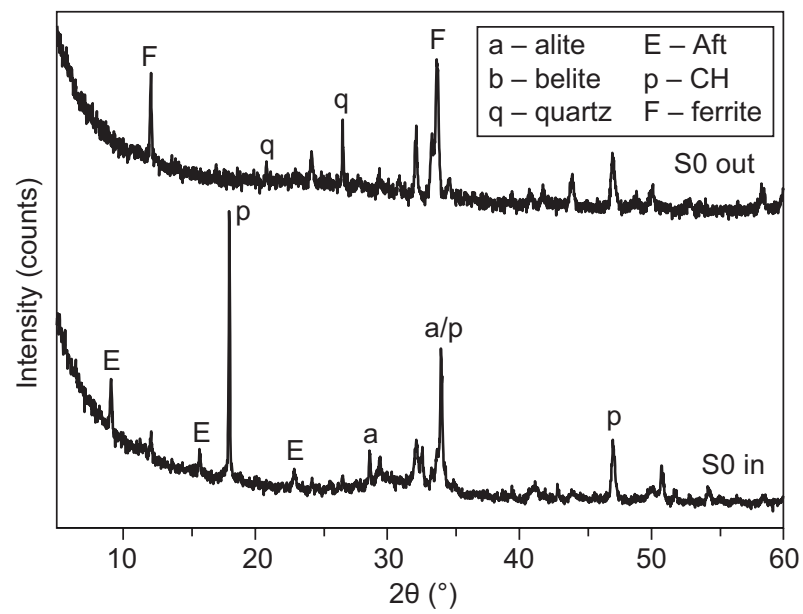

b) Hydrated cement paste at after 90 days leaching

Figure 6. XRD patterns of cement pastes hydrated at different ages after carbonic acid leaching from the surface (top curves) and the interior (bottom curves) of the specimens. 
Figure 7 shows the XRD patterns of the samples from the interior and surface of samples of cement pastes mixed with $30 \%$ fly ash after leaching. The fly-ashcontaining cement pastes and the pure cement pastes show similar variations during the leaching process. However, there were a few differences between the two pastes. For example, the $\mathrm{CH}$ content of samples from the interior was obviously lower when fly ash was used, and the $\mathrm{SiO}_{2}$ content of the surface samples was higher than in the pure cement pastes.

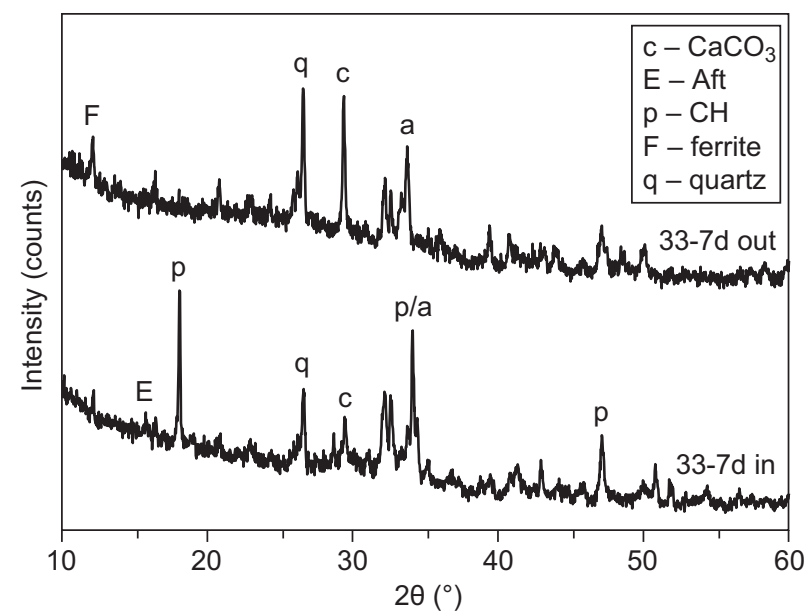

a) Hydrated $30 \%$ fly ash-cement paste after 7 days leaching

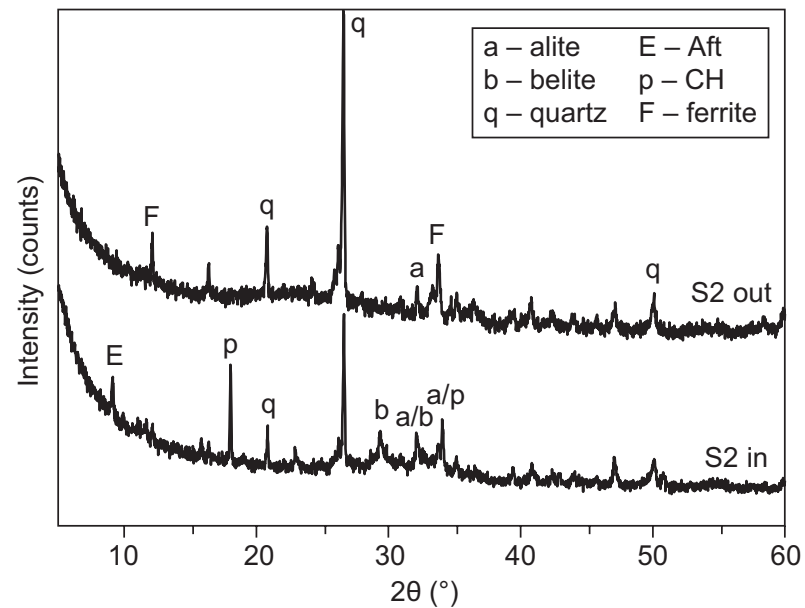

b) Hydrated $30 \%$ fly ash-cement paste after 90 days leaching

Figure 7. XRD patterns of cement pastes mixed with $30 \%$ fly ash hydrated at different age after carbonic acid leaching from the surface (top curves) and the interior (bottom curves) of the specimens.

\section{2) Samples cured in water for 28 days at $20^{\circ} \mathrm{C}$ before leaching}

As shown in Figures 8 and 9, there was a gradual decrease in the intensity of the $\mathrm{CH}$ diffraction peaks in both the interior and the surface of cement paste bodies. The $\mathrm{CH}$ content was lower on the surface than in the interior when the leaching time was the same. $\mathrm{CaCO}_{3}$ diffraction peaks were evident in the XRD patterns of three distinct leaching times; they were formed by the reaction of $\mathrm{CH}$ with carbonic acid in hardened paste. Moreover, the $\mathrm{CaCO}_{3}$ diffraction peaks of the sample surface clearly increased as leaching time increased, indicating that the corrosion product $\mathrm{CaCO}_{3}$ exhibited significant adhesion on the surface of the cement paste. Similar to pure cement paste, the intensity of $\mathrm{CH}$ diffraction peaks decreased significantly. Additionally, due to the effects of long-term leaching, the $\mathrm{CH}$ content on the surface decreased significantly for samples with $30 \%$ slag powder. The $\mathrm{CH}$ diffraction intensity was almost negligible after leaching for 180 days. Each sample exhibited a certain level of $\mathrm{CaCO}_{3}$ diffraction that obviously correlated with leaching time. Moreover, $\mathrm{CaCO}_{3}$ showed a tendency to react with aluminate hydrates, forming hydrated tricalcium aluminate carbonate $\mathrm{C}_{3} \mathrm{~A} \cdot 3 \mathrm{CaCO}_{3} \cdot \mathrm{nH}_{2} \mathrm{O}(0.941,0.251,0.380 \mathrm{~nm})$.

Figure 10 shows that the diffraction peaks of mullite and low-quartz were evident as a result of adding fly ash. Similar to pure cement paste, the intensity of $\mathrm{CH}$

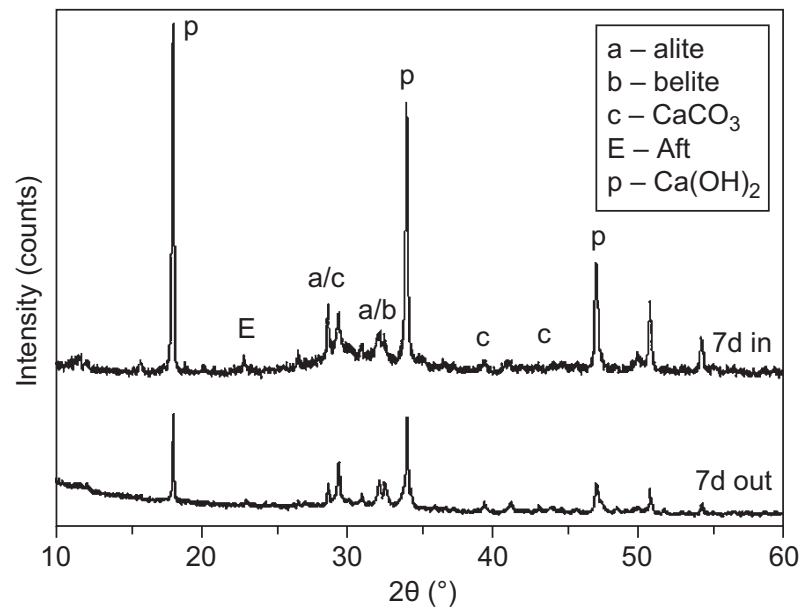

a) Cement paste after 7 days leaching

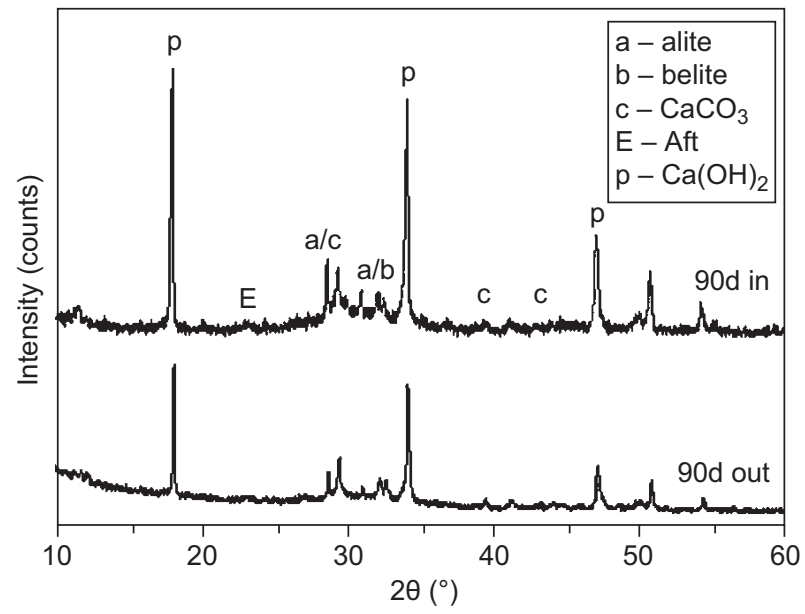

b) Cement paste after 90 days leaching

Figure 8. XRD patterns of cement pastes hydrated at different age after carbonic acid leaching (curing 28 days). 
diffraction peaks decreased significantly as the leaching time increased. Table 4 summarizes and compares the $\mathrm{XRD}$ results by listing the phases present or absent in the interior and at the surface of the specimens, respectively.

\section{Fourier-transform infrared spectroscopy}

Figure 11 presents the FTIR spectra for the interior and surface samples of the cement pastes, hydrated for 7 and 90 days, respectively. Due to the high $\mathrm{CH}$ content in cement paste, Figure 11a clearly shows that the $\mathrm{OH}$ band of $\mathrm{CH}$ at $3640 \mathrm{~cm}^{-1}$ became stronger during hydration. The band at $973 \mathrm{~cm}^{-1}$ was associated with the presence of Si-O stretching vibrations $v_{3}$ of $\mathrm{C}_{3} \mathrm{~S}_{2} \mathrm{H}_{4}(\mathrm{C}-\mathrm{S}-\mathrm{H}$ phase $)$. The strong band centered at $1485 \mathrm{~cm}^{-1}$ can be ascribed to $\mathrm{C}-\mathrm{O}$ stretching vibrations in carbonates. Finally, the broad band from 1096 to $1152 \mathrm{~cm}^{-1}$ occurred due to $\mathrm{S}-\mathrm{O}$ stretching vibrations in sulfates [6-7].

Comparing the FTIR spectra of pastes before and after carbonic acid leaching, one may conclude that the

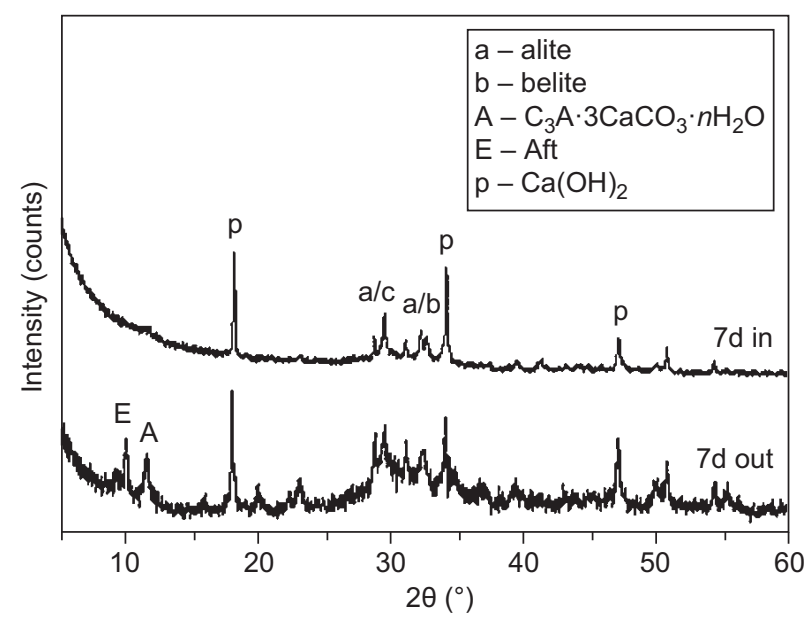

a) Cement paste after 7 days leaching

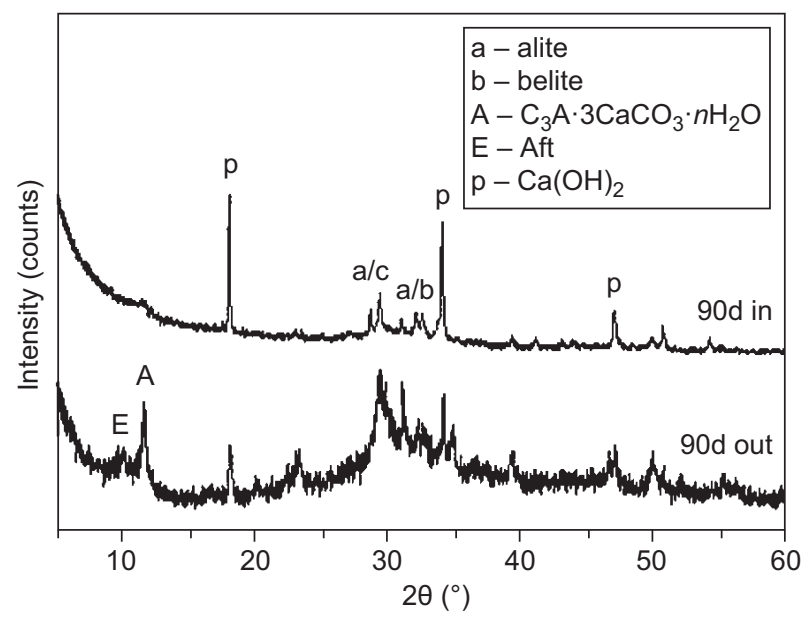

b) Cement paste after 90 days leaching

Figure 9. XRD patterns of cement pastes mixed with slag powder hydrated at different age after carbonic acid leaching (curing 28 days).
$\mathrm{CH}$ content of the cement paste greatly decreased during the carbonic acid leaching process, which agrees with the XRD results. Moreover, the $\mathrm{C}-\mathrm{O}$ stretching vibrations band became stronger, indicating the formation of calcium carbonate at the pastes' surface. Moreover, again consistent with the XRD results, the $\mathrm{OH}$ band of $\mathrm{CH}$ and the $\mathrm{C}-\mathrm{O}$ band of carbonate became much weaker after 90 days of leaching, showing that there was almost no calcium carbonate after a long leaching period. Furthermore, the $\mathrm{Si}-\mathrm{O}$ bond at $973 \mathrm{~cm}^{-1}$ was observed shifting towards higher values during the leaching period. For instance, it shifted to the sites of 1014 and $1045 \mathrm{~cm}^{-1}$, corresponding to the vibrations of crystalline quartz, after 7 and 90 days. All of the above indicates that the amount of $\mathrm{Si}-\mathrm{O}$ bonds increased during leaching.

Figure 12 shows the FTIR spectra of the surfaces and interiors of the samples of cement pastes mixed with $30 \%$ fly ash and leached for 7 and 90 days, respectively. When $30 \%$ fly ash was used, the $\mathrm{O}-\mathrm{H}$ band of $\mathrm{CH}$

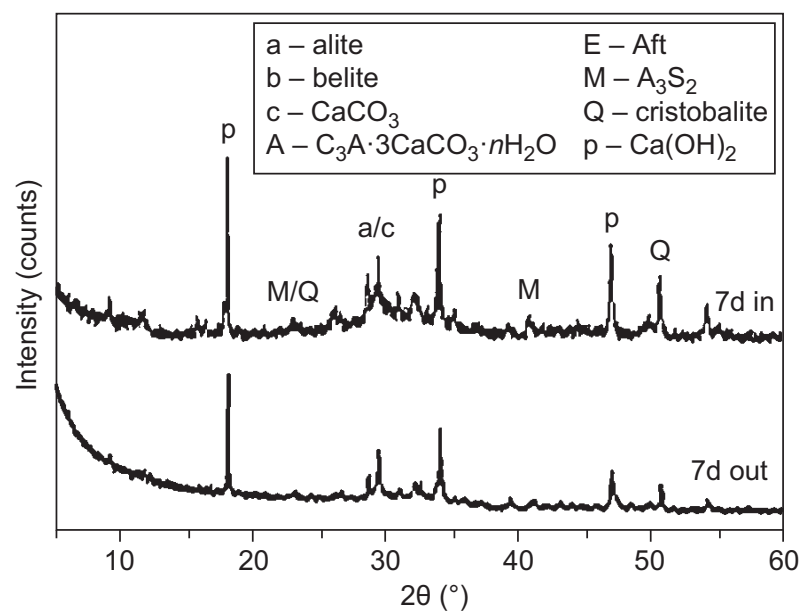

a) Cement paste after 7 days leaching

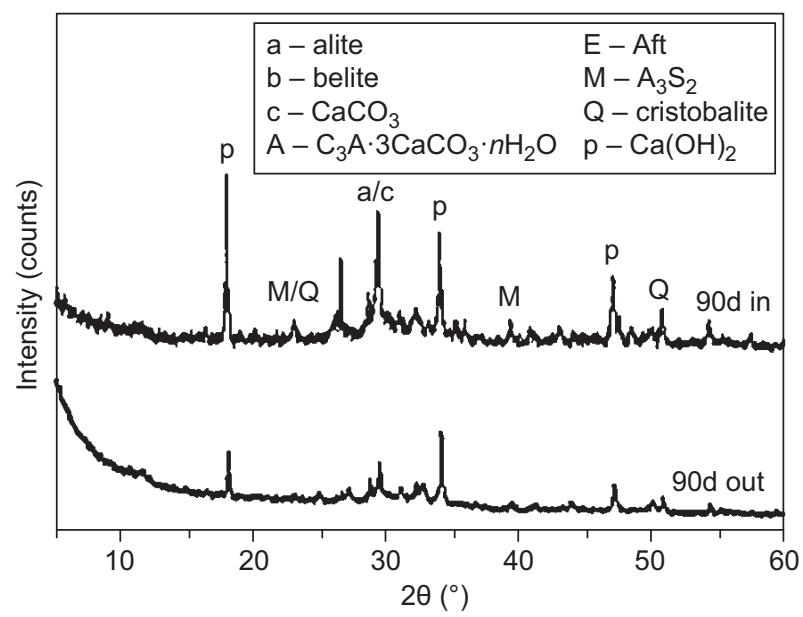

b) Cement paste after 90 days leaching

Figure 10. XRD patterns of cement pastes mixed with fly ash and slag powder hydrated at different age after carbonic acid leaching (curing 28 days). 
decreased in terms of intensity. In addition, similarly to the phase change of C-S-H in cement paste, the leaching process also influenced the structure of C-S-H in fly ash-cement paste. Consistent with the XRD results, this was evidenced by the Si-O bond shifting towards higher values, indicating the formation of $\mathrm{SiO}_{2}$ phase in the fly ash-cement pastes.
Discussion of the leaching mechanism

We can conclude from the phase analysis above that carbonic acid leaching occurred gradually, starting at the surface and moving into the interior of the pastes. The $\mathrm{CH}$ content in the pastes decreased, the $\mathrm{C}-\mathrm{S}-\mathrm{H}$ phase suffered slight damage during the early-stage leaching.

Table 4. Summary and comparison of the XRD results (phases present or absent in the interior and at the surface of the specimens, respectively); surface $=$ out, interior $=$ in. $\mathrm{A}=$ Alite, $\mathrm{B}=$ Belite, $\mathrm{C}=\mathrm{CaCO}_{3}, \mathrm{E}=\mathrm{Aft}$ (ettringite), $\mathrm{F}=\mathrm{Ferrite}, \mathrm{P}=\mathrm{Ca}(\mathrm{OH})_{2}, \mathrm{q}=$ Quartz, $\mathrm{Al}=\mathrm{C}_{3} \mathrm{~A} \cdot 3 \mathrm{CaCO}_{3} \cdot n \mathrm{H}_{2} \mathrm{O}, \mathrm{Q}=$ cristobalite.

\begin{tabular}{|c|c|c|c|c|c|c|c|c|c|c|c|}
\hline \multicolumn{2}{|c|}{ Figure } & \multirow{2}{*}{$\frac{\mathrm{A}}{\mathrm{O}}$} & \multirow{2}{*}{$\frac{B}{0}$} & \multirow{2}{*}{$\frac{\mathrm{C}}{\mathrm{O}}$} & \multirow{2}{*}{$\frac{E}{\times}$} & \multirow{2}{*}{$\frac{\mathrm{F}}{\mathrm{O}}$} & \multirow{2}{*}{$\frac{P}{\times}$} & \multirow{2}{*}{$\frac{\mathrm{q}}{\mathrm{o}}$} & \multirow{2}{*}{$\frac{\mathrm{Al}}{\times}$} & \multirow{2}{*}{$\frac{\mathrm{M}}{\times}$} & \multirow{2}{*}{$\frac{Q}{\times}$} \\
\hline 60 & 03-7d-out & & & & & & & & & & \\
\hline oa & $03-7 d$ in & $\circ$ & $\circ$ & $\times$ & ० & $x$ & $\circ$ & $x$ & $\times$ & $\times$ & $x$ \\
\hline \multirow{2}{*}{$6 b$} & S0 out & $x$ & $x$ & $x$ & $x$ & ० & $x$ & ० & $x$ & $\times$ & $x$ \\
\hline & $\mathrm{S} 0$ in & ○ & $\times$ & $x$ & $\circ$ & $\times$ & ○ & $x$ & $x$ & $x$ & $x$ \\
\hline \multirow{2}{*}{$7 \mathrm{a}$} & $33-7 d$ out & O & $\times$ & ○ & $\times$ & ○ & $\times$ & ० & $\times$ & $\times$ & $x$ \\
\hline & $33-7 d$ in & ० & $\times$ & O & ० & $\times$ & ○ & ○ & $x$ & $x$ & $x$ \\
\hline \multirow{2}{*}{$7 b$} & S2 out & O & $\times$ & $\times$ & $\times$ & ○ & $x$ & ० & $x$ & $x$ & $x$ \\
\hline & $\mathrm{S} 2$ in & ० & ○ & $\times$ & ० & $\times$ & $\circ$ & $\circ$ & $\times$ & $\times$ & $\times$ \\
\hline \multirow{2}{*}{$8 \mathrm{a}$} & $7 \mathrm{~d}$ out & ○ & ○ & O & O & $\times$ & ० & $x$ & $\times$ & $\times$ & $x$ \\
\hline & $7 \mathrm{~d}$ in & $\times$ & $x$ & $x$ & $x$ & $x$ & $x$ & $x$ & $x$ & $\times$ & $x$ \\
\hline \multirow{2}{*}{$8 b$} & 90d out & ० & O & O & ० & $\times$ & ० & $x$ & $\times$ & $x$ & $x$ \\
\hline & $90 \mathrm{~d}$ in & $\times$ & $x$ & $x$ & $\times$ & $x$ & $x$ & $x$ & $\times$ & $\times$ & $\times$ \\
\hline \multirow{2}{*}{$9 \mathrm{a}$} & $7 \mathrm{~d}$ out & o & ० & o & $\times$ & $x$ & O & $x$ & $x$ & $\times$ & $x$ \\
\hline & $7 \mathrm{~d}$ in & $x$ & $\times$ & $x$ & O & $x$ & $x$ & $x$ & ० & $x$ & $x$ \\
\hline \multirow{2}{*}{$9 b$} & 90d out & O & O & O & $\times$ & $x$ & ○ & $\times$ & $\times$ & $x$ & $x$ \\
\hline & $90 \mathrm{~d}$ in & $\times$ & $\times$ & $\times$ & $\circ$ & $\times$ & $\times$ & $x$ & O & $x$ & $\times$ \\
\hline \multirow{2}{*}{$10 \mathrm{a}$} & $7 \mathrm{~d}$ out & ० & $\times$ & o & $\times$ & $\times$ & O & $x$ & $\times$ & O & ○ \\
\hline & $7 \mathrm{~d}$ in & $\times$ & $\times$ & $\times$ & $\times$ & $\times$ & $\times$ & $x$ & $\times$ & $\times$ & $\times$ \\
\hline \multirow{2}{*}{$10 b$} & 90d out & $\circ$ & $x$ & 0 & $x$ & $\times$ & ० & $x$ & $x$ & o & ○ \\
\hline & $90 \mathrm{~d}$ in & $x$ & $x$ & $x$ & $x$ & $x$ & $x$ & $x$ & $x$ & $x$ & $x$ \\
\hline
\end{tabular}

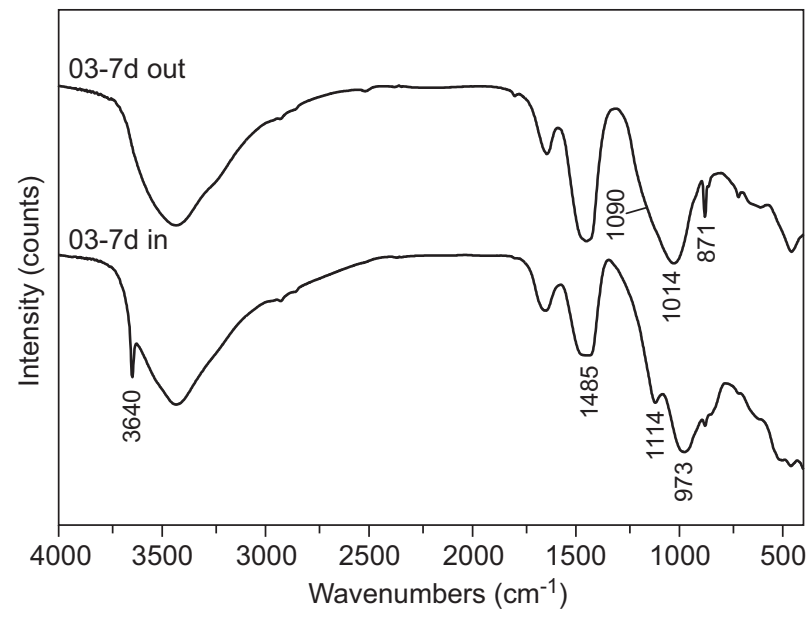

a) Cement pastes hydrated for 7 days after carbonic acid leaching

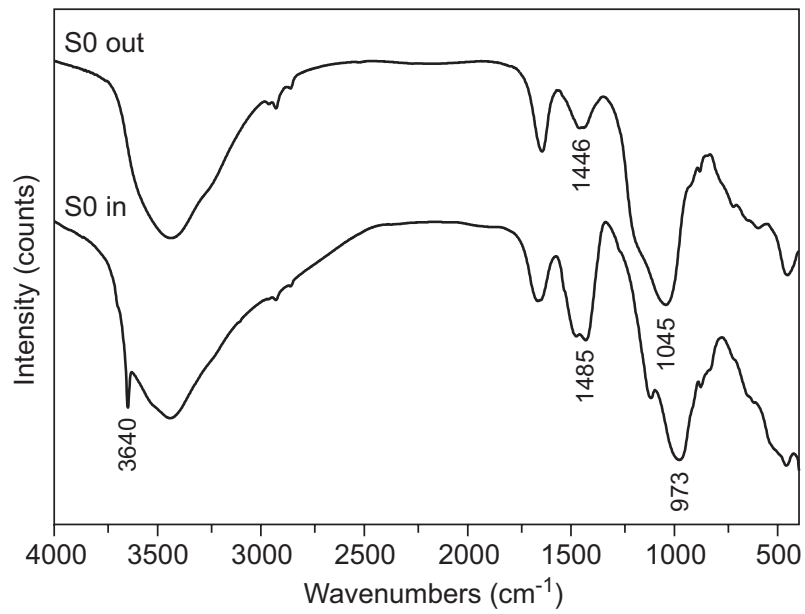

b) Cement pastes hydrated for 90 days after carbonic acid leaching

Figure 11. FTIR spectra of the internal samples and surface (cement). 


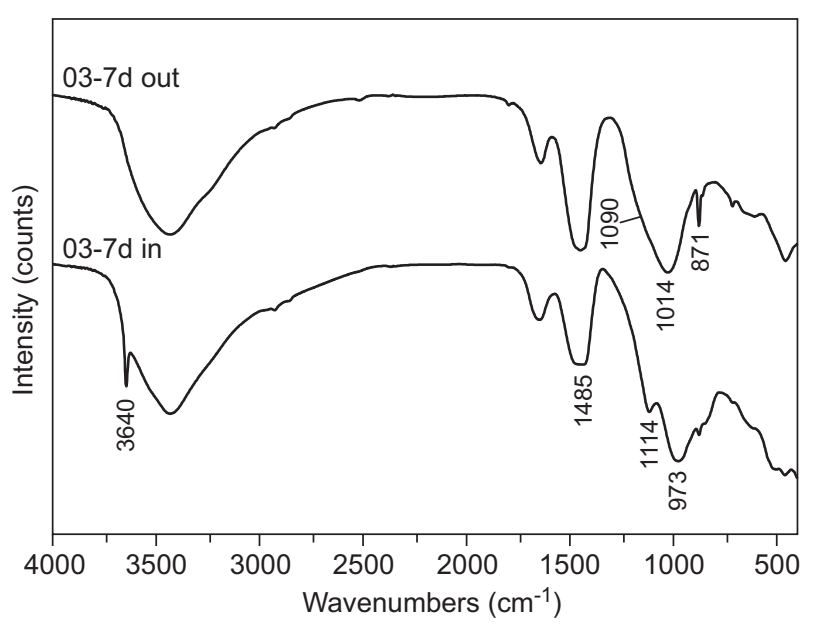

a) Cement pastes hydrated for 7 days after carbonic acid leaching

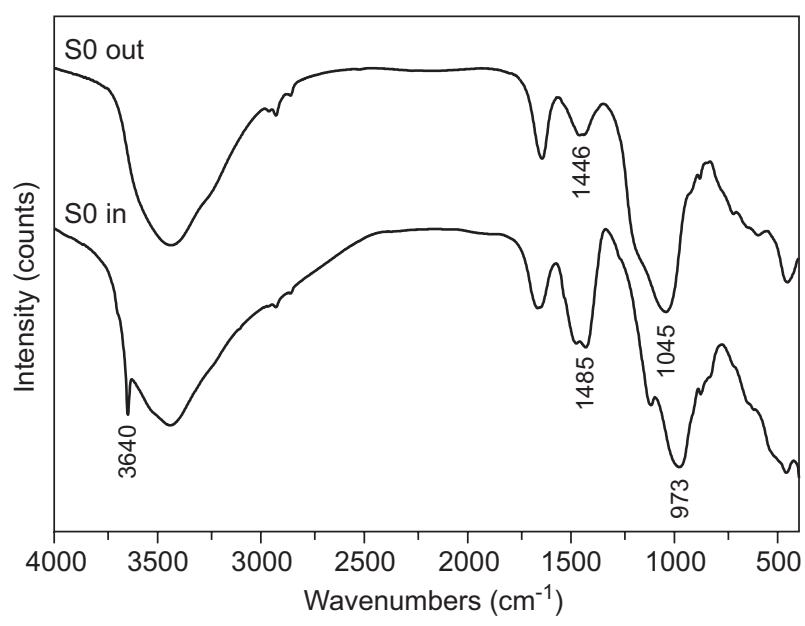

b) Cement pastes hydrated for 90 days after carbonic acid leaching

Figure 12. FTIR spectra of the interior and the surface of samples (cement pastes mixed with $30 \%$ fly ash).

The leaching products were calcium carbonate, with a small quantity of $\mathrm{SiO}_{2}$ and ferrite phases. After leaching for 90 days, there was no calcium carbonate or $\mathrm{CH}$ on the cement surface. The main products of leaching were $\mathrm{SiO}_{2}$ and ferrite phases, and the $\mathrm{C}-\mathrm{S}-\mathrm{H}$ phase suffered serious damage.

The deterioration of cement pastes via carbonic acid leaching can be divided into two steps: (1) the carbonate reaction between the cement hydration product $\mathrm{CH}$ and carbonic acid will continue until all $\mathrm{CH}$ is consumed, resulting in the formation of water-soluble calcium salts, and (2) the carbonic acid continues reacting with the $\mathrm{C}-\mathrm{S}-\mathrm{H}$ phase, obviously leading to calcium loss from the $\mathrm{C}-\mathrm{S}-\mathrm{H}$ phase. The structure of the $\mathrm{C}-\mathrm{S}-\mathrm{H}$ phase is damaged, resulting in the formation of leaching products such as crystalline $\mathrm{SiO}_{2}$, aluminate and ferrite phases. When carbonic acid leaching occurs, the structure of hydration products is damaged, calcium is leached out of the pastes, the porosity increases, and the carbonic acid leaching finally reaches the interior parts of the pastes. This results in a gradual decrease in the compressive strength of the pastes.

Incorporating less than $20 \%$ of fly ash replacement in Portland cement is an effective way to improve the carbonic acid leaching resistance. At various stages of carbonic acid leaching, mass loss of fly ash-cement pastes and compressive strength were lower than those of the cement pastes. Due to the pozzolanic reaction between fly ash and $\mathrm{CH}$, this may be associated with the decrease in alkalinity that reduced the rate of carbonate reaction and produced hydration products with a low calcium-to-silicon ratio. However, the cement pastes were more vulnerable to carbonic acid leaching when the fly ash content and slag powder exceeded $20 \%$. In the light of these findings, the optimal amount of fly ash or slag powder replacement in cement is $20 \%$.

\section{CONCLUSION}

The results of this paper lead to the following conclusions:

- When $20 \%$ fly ash or slag powder was added, the carbonic acid leaching resistance of cement pastes improved, i.e. the relative mass loss of cement pastes containing $20 \%$ of fly ash, $20 \%$ of slag powder, or $20 \%$ of both, was lower than that of pure cement pastes. However, the cement paste became more vulnerable to carbonic acid leaching damage when too much, e.g. $40 \%$, of fly ash or slag powder was added. The 90-day compressive strength of cement paste with $20 \%$ of fly ash, $20 \%$ of slag powder, or $20 \%$ of both, was greater than that of the pure cement paste.

- The carbonic acid leaching resistance of the specimens improved when cured before leaching. The degree of carbonic acid leaching resistance was higher as the curing time was longer. Both X-ray diffraction and Fourier-transform infrared spectroscopy confirm that carbonic acid leaching occurred gradually from the surface to the interior of the pastes.

- Incorporating a specific amount of slag powder helps to densify the paste. Mixing paste with fly ash and slag powder, both in amounts not exceeding $20 \%$, affects the early age hydration activity and also improves the carbonic acid leaching resistance due to the pozzolanic activity of late-age fly ash. Carbonic acid reacts with $\mathrm{CH}$ at the surface of the paste and the C-S-H phase suffers slight damage during the early leaching stages. The leaching products at this stage are calcium carbonate as well as small quantities of $\mathrm{SiO}_{2}$ and ferrite phases. After long periods of leaching the $\mathrm{C}-\mathrm{S}-\mathrm{H}$ phase at the surface of the paste suffers serious damage, and $\mathrm{SiO}_{2}$ and ferrite phases are the primary products of leaching. 


\section{Acknowledgment}

National Natural Science Foundation of China, project (51139001,51109015 and 51539002); Central Non-Profit Scientific Research Fund for Institutes (No. CKSF2016003/CL).

\section{REFERENCES}

1. Li S. (2008): Analysis on corrosivity change of groundwater of engineering site. Popular Science \& Technology, 7, 70-73.

2. Xu Y., Fang K. (2004): Diagnosis and evaluation for irrigation structures aging and destruction, China Water Power Press, 2, 182-190.

3. Wang K. (2008). Research of corrosion mechanism and prevention technique of cement-based materials under acid rain corrosion condition. Wuhan University of Technology

4. Mollah M. Y. A., Tsai Y. N., Cocke D. L. (1992): An FTIR investigation of cement based solidification/stabilization systems doped with cadmium. Journal of Environmental Science and Health Part A: Environmental Science and Engineering and Toxicology, 27(5), 1213-1227. doi:10.1080/10934529209375792

5. Cocke D. L, Hylton G., McWhinney G, Dufner D. C., Horrell B., Ortego J. D.(2009): An XPS and EDS investigation of Portland cement doped with $\mathrm{Pb}^{2+}$ and $\mathrm{Cr}^{3+}$ cations. Hazardous Waste and Hazardous Materials, 6(3), 251-267. doi: 10.1089/hwm.1989.6.251

6. Suzuki K., Nishikawa T., Ito S. (1985): Formation and carbonation of $\mathrm{C}-\mathrm{S}-\mathrm{H}$ in water. Cement and Concrete Research, 15(2), 213-224. doi:10.1016/0008-8846(85) 90032-8

7. Bensted J. (1976): Examination of the hydration of slag and pozzolanic cement by infrared spectroscopy. Cement, 73(4), 209-214
8. Zhang Y., Sun W. (2002): Influence of Mineral additive on chemical corrosion resistance of high-strengh mortar. Journal of Southeast University (Natural Science Editon), 32(2), 241-244.

9. Barmatov E. B., Hughes T., Nagl M. (2015): Efficiency of film-forming corrosion inhibitors in strong hydrochloric acid under laminar and turbulent flow conditions. Corrosion Science, 92, 85-94. doi:10.1016/j.corsci.2014.11.038

10. Zeng L., Zhang G., Guo X. P. (2014): Erosion-corrosion at different locations of X65 carbon steel elbow. Corrosion Science, 85(4), 318-330. doi:10.1016/j.corsci.2014.04.045

11. GB 50287-2006, The Geographic Survey Code of Hydroelectric Project. Standardization Administration of the People's Republic of China. 2006

12. Seifert P., Hickling J., Lister D.(2012): Corrosion and environmentally-assisted cracking of carbon and low-alloy steels-5.06.Comprehensive Nuclear Materials, 105-142. doi:10.1016/B978-0-08-056033-5.00081-1

13. Ferrer F., Faure T., Goudiakas J.(2002): Acoustic emission study of active-passive transitions during carbon steel erosion-corrosion in concentrated sulfuric acid. Corrosion Science, 44(7),1529-1540. doi:10.1016/S0010938X(01)00148-2

14. Almeida L. A., de Castro A. H., de Mendonça F. G., de Mesquita J. P. (2016): Characterization of acid functional groups of carbon dots by nonlinear regression data fitting of potentiometric titration curves. Applied Surface Science, online 15_02, 486-495. doi:10.1016/j.apsusc.2016.02.128

15. Suganuma S., Nakajima K., Kitano M., Yamaguchi D., Hideki K., Hayashi S., Michikazu H. (2010): Synthesis and acid catalysisof cellulose-derived carbon-based solid scid. Solid State Sciences, 12(6), 1029-1034.doi:10.1016/j. solidstatesciences.2010.02.038

16. GB 178-1997, The Standard Sand Applied for the Cement Strength Test. Standardization Administration of the People's Republic of China. 1997 